\title{
Regeneration of Sensory Cells after Laser Ablation in the Lateral Line System: Hair Cell Lineage and Macrophage Behavior Revealed by Time-Lapse Video Microscopy
}

\author{
Jay E. Jones and Jeffrey T. Corwin \\ Department of Otolaryngology-l Head and Neck Surgery and Department of Neuroscience, School of Medicine, University \\ of Virginia, Charlottesville, Virginia 22908
}

The regeneration of sensory hair cells in lateral line neuromasts of axolotls was investigated via nearly continuous time-lapse microscopic observation after all preexisting hair cells were killed by a laser microbeam. The laser treatments left neuromasts with one resident cell type, which was supporting cells. Over the course of 1 week, replacement hair cells arose either directly via differentiation of cells present in the epithelium from the beginning of the time-lapse period or via the development of cells produced after one or two divisions of supporting cells. All of the cell divisions that produced hair cells were asymmetrical.

During the first hour after the treatment, macrophages and smaller leukocytes were attracted to the laser-treated neuromasts. The smaller leukocytes returned to control levels 48-60 $\mathrm{hr}$ after the treatment, whereas macrophages remained active there throughout the period of hair cell replacement. Macro- phage incidence peaked $36-48 \mathrm{hr}$ after the laser treatment. Macrophages phagocytosed damaged hair cells and supporting cells, as well as new cells and preexisting cells without recognizable damage.

The results provide direct evidence of hair cells arising as progeny produced from the divisions of supporting cells, evidence of hair cells and supporting cells arising from the same cell division, evidence relating to the timing of hair cell differentiation, and indirect evidence pertaining to proposals that hair cells sometimes arise via conversion of cells without an intervening division. The results also suggest that macrophages may influence early stages in the process of hair cell regeneration.

Key words: hair cells; regeneration; lineage; macrophages; lateral line; development
Sensory hair cells of vertebrate auditory, vestibular, and lateral line sensory epithelia transduce mechanical stimuli into transmembrane electrical activity that is transmitted to the brain by cranial nerves. Loss of hair cells can result from exposure to loud sound, infections, and poisoning by aminoglycoside antibiotics or chemotherapy agents, or as a consequence of aging. In mammals, production of auditory hair cells generally is limited to the period of embryonic development (Ruben, 1967; Bredberg, 1968); therefore, sensory deficits that result from postembryonic loss of hair cells have been considered to be irreversible. In contrast, postembryonic production of hair cells occurs throughout life in the auditory and vestibular epithelia of fish and amphibians (Corwin, 1981, 1983, 1985; Jørgensen, 1981; Popper and Hoxter, 1984), in the vestibular epithelia in birds (J 0 rgensen and Mathiesen, 1988; Roberson et al., 1992), and in the neuromast organs of the lateral line systems of amphibians and fish (Stone, 1933, 1937; Speidel, 1947, 1948; Wright, 1947; Tester and Kendall, 1969; Corwin, 1986; Corwin et al., 1989). Hair cell epithelia also can exhibit remarkable self-repair after trauma (Cotanche, 1987). When avian hair

Received June 6, 1995; revised Oct. 10, 1995; accepted Oct. 20, 1995.

This work was supported by a grant from NIDCD and funds from the Lions of Virginia Hearing Foundation to J.T.C. We thank Mark Warchol, Matthew Kelley, and Akiko Katayama Lau for comments and advice, and Susan Duhon and the staff of the Indiana University axolotl colony for advice and a reliable supply of axolotls, and Dr. Michael Berns and the Beckman Laser Institute and Medical Clinic.

Correspondence should be addressed to Jeffrey $\mathrm{T}$. Corwin, Department of Otolaryngology-Head and Neck Surgery and Department of Neuroscience, Box 396, School of Medicine, University of Virginia, Charlottesville, VA 22908.

Jay E. Jones' present address: Cato Rescarch, 4364 Alston Avenue, Suite 201, Durham, NC 27713.

Copyright (c) 1996 Society for Neuroscience 027()$-6474 / 96 / 160649-14 \$ 05.00 / 0$ cells have been killed by loud sound, the mitotically quiescent cochlear sensory epithelium responds with cell divisions at the site of damage, leading to the formation of replacement hair cells (Corwin and Cotanche, 1988; Ryals and Rubel, 1988). Administration of tritiated thymidine after acoustic trauma to that epithelium demonstrated the presence of newly replicated DNA both in hair cells and in supporting cells at the sites of regeneration. Therefore, the question arose as to what types of cells divided during hair cell regeneration.

The body of indirect evidence strongly favors a role for supporting cells as the progenitors of replacement hair cells (Corwin, 1986; Corwin and Cotanche, 1988; Girod et al., 1989; Katayama and Corwin, 1989, 1993; Corwin et al., 1991; Raphael, 1992, 1993; Weisleder and Rubel, 1993), but several other cell types have been proposed as potential progenitors for hair cells. These types have included the following: hyaline and cuboidal cells that reside outside the inferior edge of the sensory epithelium in the avian cochlea (Girod et al., 1989; Rubel et al., 1991); border cells, a subset of supporting cells that have been classified as such because of their position as the outermost supporting cells at the inferior edge of that same sensory epithelium (Oesterle et al., 1992); and neuroepithelia-like cells that have been reported to be distributed throughout sensory epithelia in the ears of teleost fish (Presson and Popper, 1990; Presson et al., 1994).

In the context of indirect evidence that led to uncertain conclusions, the present study was designed to provide direct observations of cell lineages leading to regenerated hair cells. The experiments took advantage of the observation that hair cells can be regenerated in lateral line organs after all preexisting hair cells 
have been killed (Balak et al., 1990). The use of time-lapse recording allowed unambiguous determination of the timing and the positions of cell divisions as the time lapse record of events was reviewed in reverse, providing direct visualization of the lineage relationships of hair cells and supporting cells and visualization of the actions of leukocytes during the formation of the replacement hair cells.

\section{MATERIALS AND METHODS}

Juvenile albino axolotls (Ambystoma mexicanum) were obtained from the Indiana University axolotl colony and were maintained in $20 \%$ Holtfreter's solution at $10^{\circ} \mathrm{C}$ to retard growth until they were needed for experimentation. Axolotls were fed live brine shrimp larvae at least every other day. A supply of axolotls that ranged in size from 15 to $25 \mathrm{~mm}$ was acclimated to room temperature for at least $3 \mathrm{~d}$ before each experiment.

Identification of cells. The lateral line system in axolotls develops in the skin from proliferative migratory cells that originate in cranial ectodermal placodes (Harrison, 1904; Stone, 1933; Winklbauer and Hausen, 1983a; Northcutt et al., 1994). A recent report has proposed that the neuromasts of this system also contain cells from the neural crest (Callazo et al., 1994). Neuromasts of the lateral line system consist of two principal cell types: sensory hair cells and supporting cells. Hair cells and supporting cells can be distinguished reliably by using differential interference contrast (DIC) microscopy and fluorescence microscopy. Hair cells occupy a central location within neuromasts. They have spherical nuclei and apical hair bundles, and they label brightly with the vital fluorescent styryl dye

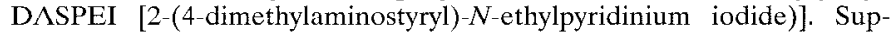
porting cells contact the basal lamina and surround the hair cells basolaterally. At least two subtypes of supporting cells are recognizable by their positions within neuromasts and their appearance in transmission electron microscopy: internal supporting cells and mantle-type supporting cells (Flock and Jørgensen, 1974; Jones and Corwin, 1993). Internal supporting cells are located where they can make physical contact with hair cells, lying either directly beneath and between the sensory cells or immediately adjacent to them on the sides. Mantle-type supporting cells form a peripheral "rind" that surrounds the internal supporting cells and hair cells. This rind of mantle-type supporting cells separates the inner cells of the neuromast from the surrounding epidermal cells.

Hair cell ablations. An initial experiment using a laser-microsurgery apparatus was conducted at the Beckman Laser Institute and Medical Clinic of the University of California (Irvine, $\mathrm{C} \Lambda$ ). That apparatus, which was described previously (Balak et al., 1990), consisted of a $1.5 \mathrm{~J}$ pulsed neodymium-yttrium-aluminum-garnet laser [355 nm ultraviolet (UV) output], beam-steering mirrors, a beam attenuator, and a Zeiss Axiomat inverted microscope equipped with a newvicon video camera with a $100 \times, 1.25$ N.A., quartz, glycerin-immersion objective lens and DIC optics. Subsequent hair cell ablation experiments were carried out at the University of Virginia using the output from a $175 \mu \mathrm{J}$ pulsed-nitrogen laser ( $337 \mathrm{~nm}$ UV output; model VSL 337ND, Laser Science, Newton, MA), which was attenuated by placing a series of glass filters in the beam path. The slight divergence of the laser beam was corrected by adjusting the separation between two plannconvex lenses ( $50.2 \mathrm{~mm}$ focal length). The beam was directed next to a dichroic mirror in the epi-illumination path of a Zeiss Axiovert inverted microscope. The microscope was equipped with a charge-coupled device video camera, a $100 \times, 1.25$ N.A., quartz, glycerin-immersion objective lens, and DIC optics.

Before the microscopic observations and cell ablations, axolotls were anesthetized by immersion in $0.007 \%$ benzocaine (ethyl-paminobenzoate) in 100\% Holtfreter's solution. They then were immersed for 1-2 min in a $100 \%$ Holtfreter's solution containing anesthetic and the vital fluorescent dye DASPEI at $1 \mathrm{~mm}$. Hair cells in neuromast sensory epithelia of the lateral line system of fish and amphibians are specifically labeled by DASPEI (Jørgensen, 1989; Balak et al., 1990). Each axolotl then was placed in an open observation chamber constructed from an aluminum base, a number 1.5 coverglass, and adhesive-backed magnetic tape. The axolotl was restrained with its tail pressed close to the coverglass bottom by minuten pins held via magnetic attachments. Then DIC and fluorescence video images of the hair cells in a neuromast that was selected for a subsequent laser treatment were recorded (Fig. 1A,B). The chamber containing the axolotl next was transferred to the stage of the laser-microsurgery microscope, and the neuromast was brought into focus using transmitted light and DIC optics. Hair cells in the neuromast were killed individually by administering $3 \mathrm{nsec}$ pulses of light emitted from the laser directed to the back aperture of the objective lens by the dichroic mirror. The objective lens brought the laser beam to focus as a $1-\mu \mathrm{m}-$ diameter spot at the plane of focus of the transmitted light image. The use of the dichroic mirror, the epi-illumination path, and a barrier filter permitted simultaneous uninterrupted observation by transmitted light DIC on a video monitor during the use of the laser microbeam (Berns et al., 1981). Individual hair cells were brought into focus at the level of their nuclei and moved to the site of cross hairs on the video monitor that marked the position of the microbeam focus. A single pulse of light from the laser usually was sufficient to kill each cell, but at times two or three pulses were given to ensure cell death. Then the microscope stage was moved to bring another hair cell nucleus into focus beneath the cross hairs, and the procedure was repeated until all of the hair cells in the neuromast had been treated.

After laser treatment, axolotls again were immersed for $1-2 \mathrm{~min}$ in Holtfreter's solution containing anesthetic and DASPEI at $1 \mathrm{mM}$. Each axolotl then was transferred to a sealed time-lapse observation chamber (Jones and Corwin, 1993), and both DIC and fluorescent images of the neuromast were obtained to verify that all of the hair cells had been killed (Fig. $1 C, D$ ). The absence of DASPEI-labeled hair cells in laser-treated epithelia indicated that the laser treatment had been effective in killing hair cells and that the treated neuromast epithelia contained only supporting cells. The supporting cells that remained after the ablations of hair cells then were visualized by DIC and nearly continuous time-lapse recording that began within $1 \mathrm{hr}$ of the laser treatment and continued until replacement hair cells had been regenerated (Fig. 1E,F). At the end of the time-lapse recording phase of the experiments, DASPEI labeling was used again. Each regenerated hair cell was identified on the basis of DASPEI labeling, an apically positioned spherical nucleus, and an apical hair bundle.

Time-lapse observations. Details of the time-lapse recording technique were reported previously (Jones and Corwin, 1993). Briefly, axolotis were anesthetized and restrained in a sealed observation chamber through which a sterile saline solution containing $0.007 \%$ benzocaine flowed continuously through a gravity feed. The chamber was disassembled and cleaned at $24-48 \mathrm{hr}$ intervals, and the axolotls were allowed to recover from anesthesia for up to $2 \mathrm{hr}$. The axolotls were fed during each break. Time-lapse records were made using a Zeiss inverted microscope fitted with an electronic shutter between the light source and the condenser. The microscope was equipped with a $40 \times$ objective lens, DIC optics, and a newvicon video camera. An image-processing system (Image-1/AT, Universal Imaging, West Chester, PA) was used to enhance the signalto-noise ratio and the contrast in the video images and to control the electronic shutter, an optical memory disk recorder, and a microstepper motor that was linked to the coarse focus knob of the microscope. At 150-180 sec intervals, the shutter was opened for $1 \mathrm{sec}$ so that the specimen was illuminated while 16 video frames were digitized and summed, and then the shutter was closed. The processed image was recorded on an optical disk, the microstepper motor adjusted the focus of the microscope to the next programmed focal plane, and the cycle of image capture was repeated. Images from three to five levels of focus were recorded in sequence on separate segments of the optical memory

Figure 1. Hair cell regeneration after the ablation of all preexisting hair cells in a lateral line neuromast using the laser microbeam. The same neuromast observed in a living axolotl is shown in all six micrographs, which were printed from individual frames in the time-lapse video record. $A$, $C, E$, DIC views of the neuromast with the focus at the normal level of the hair cell nuclei. $B, D, F$, Epifluorescent images of the same neuromast, showing the positions of living hair cells labeled by immersion in DASPEI for $2 \mathrm{~min}$. $A$, The neuromast before laser treatment. Hair cells are recognizable by the circular outlines of their centrally located nuclei. $B$, The same neuromast with the hair cells distinguishable because of their selective uptake of the brightly fluorescent DASPEI. $C, D$, The same neuromast $1 \mathrm{hr}$ after laser ablation of the hair cells and subsequent extrusion of the killed hair cells. Only supporting cells are seen. $E, F$, The neuromast $7 \mathrm{~d}$ later, after completion of nearly continuous time-lapse during regeneration that resulted in the production of three hair cells. 

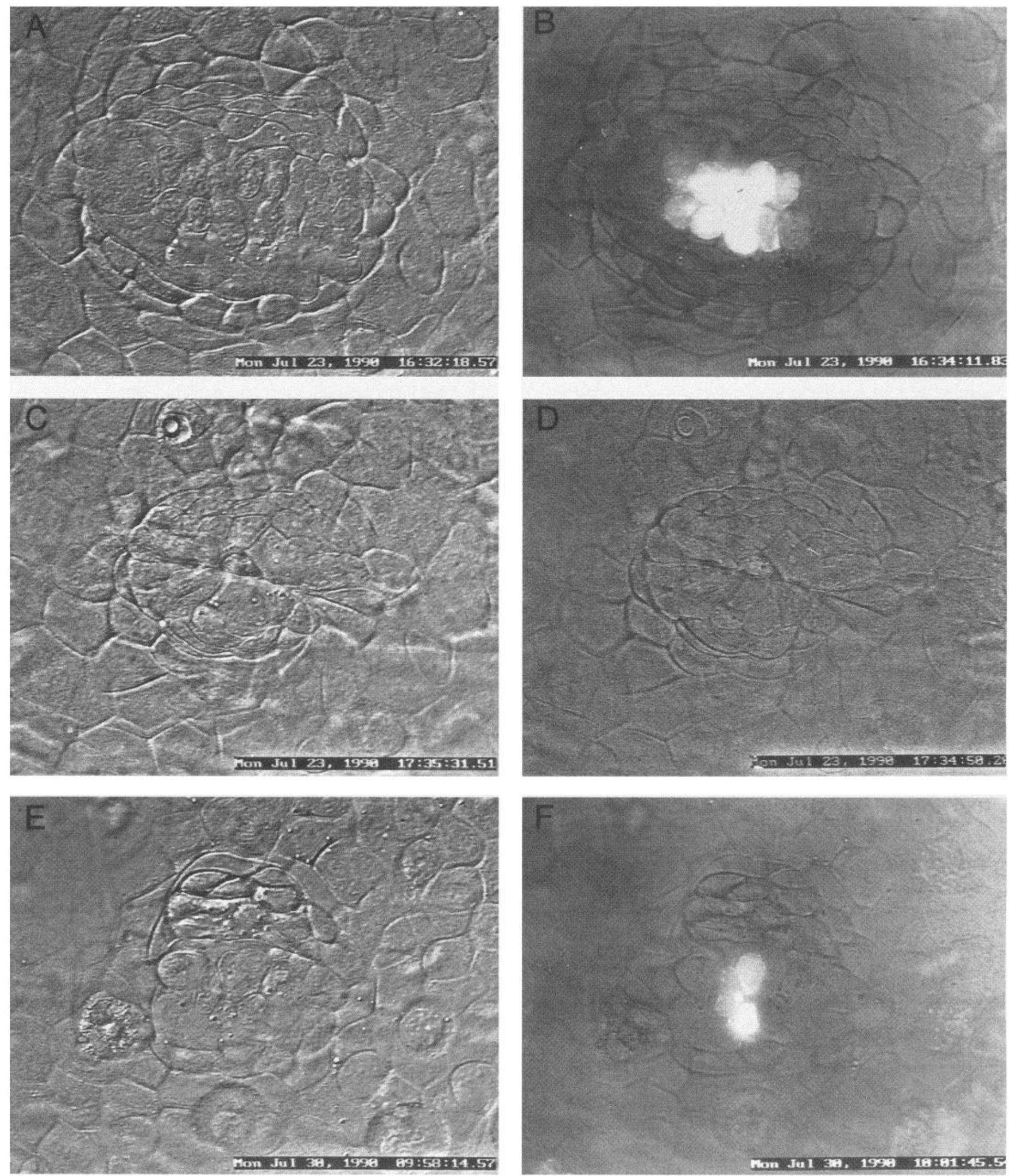
disks so that time-lapse records were produced concurrently for each level of focus through the full depth of the sensory epithelium.

In one early experiment carried out at the Beckman Laser Institute and Medical Clinic, video images were recorded on a time-lapse videocassette recorder (Gyrr, Anaheim, CA). During that experiment, the focus of the microscope was varied continuously throughout the thickness of the neuromast by using a DC motor, reduction gears, and an eccentric linkage that was attached to the focus knob.

Analysis of time-lapse data. The number of cell divisions and the types of cells involved were tabulated from time-lapse records of normally growing (control) and laser-treated (experimental) neuromasts in which all preexisting hair cells had been killed. The neuromasts were selected so that all were approximately the same size. Each contained 10-15 hair cells, 40-50 internal supporting cells, and 20-30 mantle-type supporting cells (Jones and Corwin, 1993). 'The patterns of activity of two classes of leukocytes also were quantified by tabulating their numbers and locations at $1 \mathrm{hr}$ intervals throughout the time-lapse records.

The sequence of events that led to the production of each new hair cell was determined by first identifying a regenerated hair cell near the end of a time-lapse recording. The recording then was played backward frameby-frame, and the image of the hair cell was followed. At times, the image of the hair cell or its progenitor changed because it drifted from the level of focus of the microscope. When that happened, the prominent features of the video image were traced on a transparent sheet taped to the monitor screen at a point in the time-lapse record when the cell was still reliably identifiable. Then the tracing was aligned over an image of the neuromast that had been recorded in the same time period but at a different plane of focus on a separate segment of the optical memory disk. The procedure took advantage of the concurrent recordings made at several planes of focus, which allowed the cell to be relocated and the analysis to continue. When the image of a regenerated hair cell could not be followed reliably through the time-lapse record, that hair cell and its progenitors werc excluded from further analysis. Gaps in the video record necessarily resulted from the $1-2 \mathrm{hr}$ interruptions when the axolotls were fed. The shapes of individual cells, their positions relative to each other, the contents of their cell bodies, and their nuclei usually had similar appearances before and after a break. Tracings from the monitor similar to those described above were used to identify cells of interest on either side of a break in the time-lapse record to ensure that the tabulation of events was accurate. All timles reported below are referenced to the start of the laser-microbeam treatment and not to the start of the time-lapse recording.

\section{RESULTS}

\section{Hair cell ablation}

Sensory hair cells in individual neuromasts of the lateral line were treated one at a time by pulses of the laser microbeam brought to focus in their nuclei. The initial response to laser treatment consisted of a rapid change in the nuclear envelope of the treated cells to a DIC-bright appearance. Within minutes, the bodies of treated cells usually began to move toward the sensory pore, the opening in the epidermis at the apex of the neuromast through which the hair bundles communicate with the fluid medium outside the surface of the skin. Most of the treated cells were extruded through the sensory pore of the epithelium. Hair cells that were not extruded from neuromasts usually were phagocytosed by macrophages within $24 \mathrm{hr}$ of the laser treatment, as evidenced in the time-lapse records (see below). A total of four hair cells in two axolotls survived for $24 \mathrm{hr}$ after the initial laser treatment. Those cells were treated a second time, and they were removed from the epithelia by macrophages within $12 \mathrm{hr}$ of the second laser treatment.

\section{Time-lapse observations}

The tails of albino axolotls are translucent, and the neuromasts of the lateral line are located near the surface of the skin, so living cells can be observed at high magnification in vivo using transmitted-light DIC microscopy. Time-lapse video recording of DIC images revealed cellular events that led to hair cell regener- ation after ablation of all preexisting hair cells in one neuromast in each axolotl.

\section{Leukocytes}

Time-lapse observations of lateral line epithelia revealed the presence of highly motile leukocytes. The morphological appearance, behavioral characteristics, and histochemical staining profiles of leukocytes in the tails of axolotls have been reported previously (Jones and Corwin, 1993). In the present study, leukocytes were classified as "small" and "large" based on size and morphology. The behavior (locomotion and phagocytic activity) and the histochemical characteristics suggested that most of the small leukocytes were neutrophilic granulocytes and that the large leukocytes were macrophages (Jones and Corwin, 1993).

The numbers and locations of small and large leukocytes were tabulated from time-lapse recordings of normally growing control neuromasts and experimental neuromasts that were in the process of regenerating hair cells after laser treatment. Control data were tabulated from the video records of the initial $24 \mathrm{hr}$ of time-lapse observation of one neuromast in each of six axolotls $(12 \times 12 \mathrm{hr}$ intervals for a total of $144 \mathrm{hr}$ of observation). Fxperimental data were tabulated from the initial $108 \mathrm{hr}$ of time-lapse observation of a neuromast undergoing hair cell regeneration after laser hair cell ablation in each of five axolotls $(45 \times 12 \mathrm{hr}$ intervals for a total of 540 hr of observation).

Locations were specified as the estimated positions of the centroids of the leukocytes. Three position categories were recognized: (1) in the tissue just peripheral to neuromasts, (2) among the mantle-type supporting cells of neuromasts, and (3) among the internal supporting cells of neuromasts. The incidence of leukocytes, averaged over the entire 144 hr observation in controls and over the entire $540 \mathrm{hr}$ of observation in the regenerating neuromasts, was as follows. Small leukocytes were observed most often in the tissues peripheral to the neuromasts $(26.4 \pm 1.7$ cells/12 hr of observation in experimentals; $25.6 \pm 3.8 \mathrm{cclls} / 12 \mathrm{hr}$ of observation in controls). Intermediate numbers of small leukocytes were observed among the mantle-type supporting cells (7.7 \pm 0.8 cells $/ 12 \mathrm{hr}$ of observation in experimentals; $8.4 \pm 1.0$ cells/12 hr of observation in controls). Small leukocytes seldom were observed among the internal supporting cells and hair cells $(0.4 \pm 0.1$ cells $/ 2 \mathrm{hr}$ of observation in experimentals; $0.2 \pm 0.1$ cells/12 hr of observation in controls). The differences between the mean numbers of small leukocytes in experimental and control neuromasts were not statistically significant when global averages for the entire 540 and $144 \mathrm{hr}$ observation periods were compared. In contrast, the number of large leukocytes observed in the tissue peripheral to the neuromasts increased significantly after the laser treatments, even when comparisons were made between such global averages $(6.9 \pm 0.8$ cells $/ 12 \mathrm{hr}$ in experimentals vs $0.6 \pm 0.3 / 12 \mathrm{hr}$ in controls; $p<0.01$, Student's $t$ distribution). The incidence of large leukocytes in the mantle-type supporting cell region also increased significantly $(11.3 \pm 0.9$ cells $/ 12$ $\mathrm{hr}$ in experimentals vs $1.1 \pm 0.6 / 12 \mathrm{hr}$ in controls; $p<0.01$, Student's $t$ distribution). Relatively few large leukocytes were observed in the internal regions of neuromasts as determined by charting the centroids of the leukocytes $(0.8 \pm 0.2$ cells $/ 12 \mathrm{hr}$ in experimentals; $0.1 \pm 0.6$ cells $/ 12 \mathrm{hr}$ in controls), but internal supporting cells were contacted by pseudopodia extended from large leukocytes, the centroids of which were positioned among the mantle-type supporting cells. Pseudopodial contact by large leukocytes often was a prelude to removal of cells and phagocytosis. 

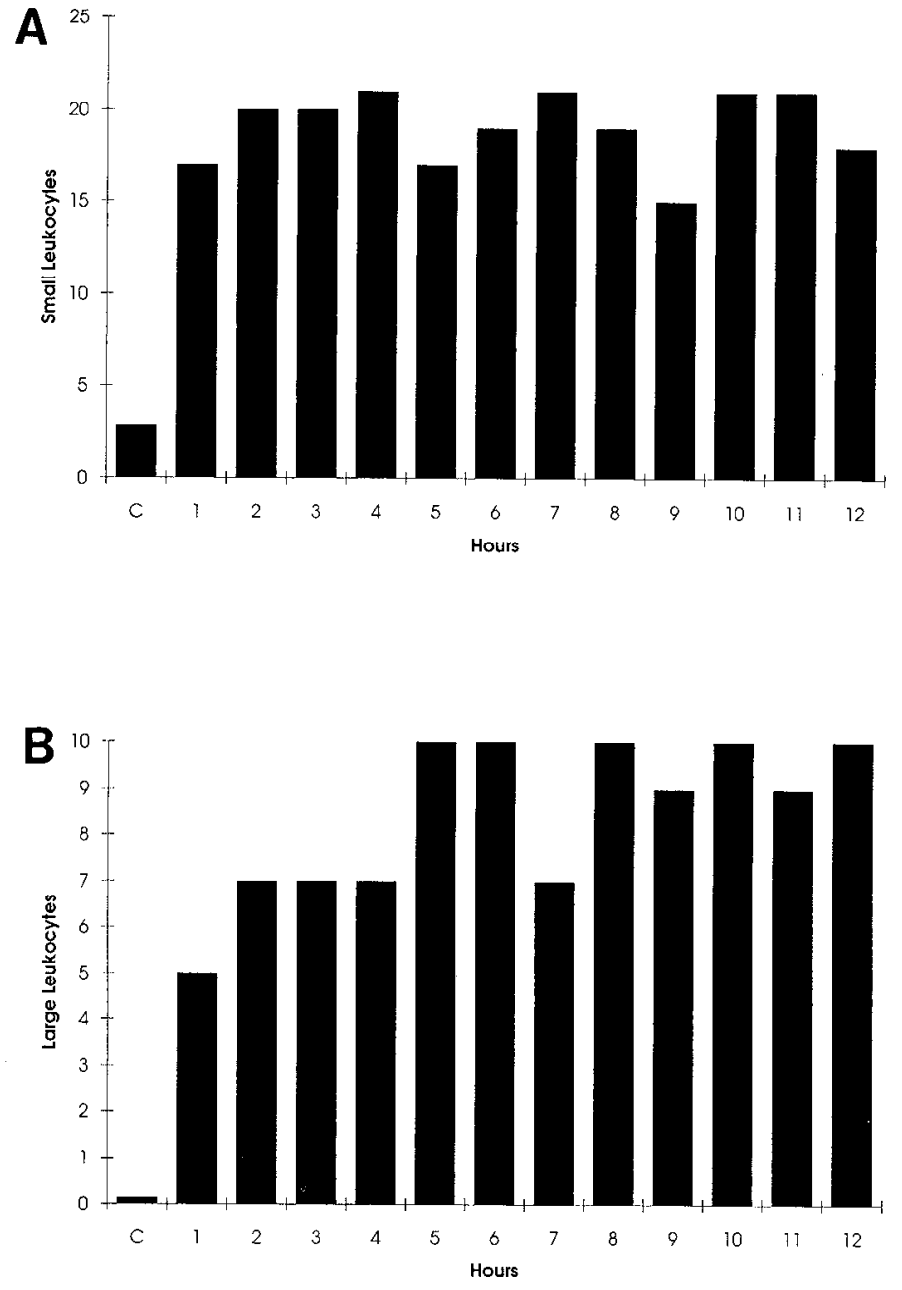

Figure 2. Histograns of the incidence of small and large leukocytes in the vicinity of control neuromasts observed by time-lapse and in the vicinity of laser-treated neuromasts, tabulated at $1 \mathrm{hr}$ intervals during the first $12 \mathrm{hr}$ after the treatment. The data have been pooled from one untreated neuromast in six control axolotis and one laser-treated neuromast in each of five axolotls. All leukocytes that were observed among the cells of the neuromast and in its immediate vicinity were pooled for each time bin. The incidence of small leukocytes is represented in $A$, and the incidence of large leukocytes is shown in $B$. The large increase between the control $(C)$ and the $1 \mathrm{hr}$ bins $(1-12)$ in each histogram demonstrates that the small and large leukocytes redistributed to the vicinity of laser-treated neuromasts in numbers that were substantially higher than the numbers observed around control neuromasts. The incidence of large leukocytes continued to increase for a few hours after the small leukocytes had reached near-maximal numbers. The difference in control incidence between the much more commonly observed small leukocytes and the large leukocytes is noteworthy (see text for additional details).

The incidence of leukocytes also was analyzed with $1 \mathrm{hr}$ temporal resolution and lower spatial resolution. The total incidence of each type of leukocyte was pooled for the three categories of position (peripheral to the neuromast, among the mantle-type supporting cells, and among the internal-type supporting cells), and those numbers were tabulated for observations made each hour. This revealed that the small (Fig. $2 A$ ) and large leukocytes (Fig. $2 B$ ) already had redistributed to the vicinity of the lasertreated neuromasts $1 \mathrm{hr}$ after the laser treatment. At that time, the small and large leukocytes were observed at $\sim 6$ and 33 times the respective incidence observed in the vicinity of control neuromasts. The incidence of both categories of leukocytes remained high in the vicinity of the treated neuromasts through several days, but the behavior of the small and large leukocyte populations became progressively different as the regencrative response continued (Fig. 3). The small leukocytes were most common in the peripheral tissues that surrounded the neuromast, where their incidence peaked during the 12-24 hr time period (Fig. 3A). Their incidence subsequently dropped, reaching control levels in the $48-60 \mathrm{hr}$ period. Their numbers remained low from that point on as regeneration continued. In contrast, the large leukocytes were most common among the mantle-type supporting cells (Fig. 3B). Among those cells, the incidence of the large phagocytic leukocytes increased markedly during the first $12 \mathrm{hr}$ period of timelapse observation after the laser treatment and then increased more slowly to a peak during the $36-48 \mathrm{hr}$ period. The number of large phagocytic leukocytes declined from that peak but remained severalfold greater than control levels throughout the entire period (108 hr) that was analyzed.

In the tails of axolotls, the behavior that uniquely distinguishes large leukocytes from small leukocytes is their phagocytosis of other cells (Jones and Corwin, 1993). After laser treatment, the rates of phagocytosis of internal supporting cells, mantle type supporting cells, and hair cells all increased significantly from control values ( $p<0.01$, Student's $t$ distribution; Table 1 ). With the exception of the laser-treated hair cells, in most experiments the morphology of the cells that were about to be phagocytosed was not readily distinguishable from that of their neighboring cells.

\section{Mitoses}

Mitoses of supporting cells were observed frequently in both control and laser-treated neuromasts, but hair cells were never ohserved in mitosis. Mitotic cells were recognized easily during DIC microscopy, particularly in the playback of time-lapse recordings.

After tail amputation, when an entire series of neuromast organs is replaced, the rate of internal supporting cell division decreases at the same time that the rate of mantle-type supporting cell division increases (Jones and Corwin, 1993). In the current study, the mitotic activitics of internal supporting cells and mantle-type supporting cells were tabulated separately to determine whether those subpopulations of supporting cells also would exhibit different rates of proliferation in response to the selective ablation of hair cells.

Under normal circumstances, the primary criterion used in distinguishing internal supporting cells from mantle-typesupporting cells is their physical proximity to hair cells. That criterion was not applicable after hair cells had been killed, so the characterization of supporting cells as internal or mantle-type was less certain and was determined by the relative positions of the cells in those neuromasts. During the initial $12 \mathrm{hr}$ interval of time-lapse observation after hair cell ablation, the mitotic activity of internal supporting cells was well below the control level $(0.2 \pm$ 0.2 mitoses $/ 12 \mathrm{hr}$ in the experimentals vs $1.9 \pm 0.3$ mitoses $/ 12 \mathrm{hr}$ in the controls; Fig. 4, top). During subsequent $12 \mathrm{hr}$ intervals, the rate of cell division in the internal supporting cell population increased to control levels. In contrast to the internal supporting cells, the mitotic activity of mantle-type supporting cells increased above the control value of $0.3 \pm 0.3$ mitoses/ $12 \mathrm{hr}$ in the first interval tabulated, and it remained above control levels during all nine $12 \mathrm{hr}$ intervals of time-lapse observation after the laser treatment (Fig. 4, bottom). The mitotic activity of mantle-type 
Figure 3. The incidence of small and large leukocytes in three regions of control and laser-treated neuromasts tabulated during $12 \mathrm{hr}$ intervals after the laser treatment. The temporal resolution of leukocyte incidence is lower in this figure than in Figure 2, but the spatial resolution is finer. $A$, The number of small leukocytes that were observed among the internal supporting cells (black bars), among the mantletype supporting cells (medium gray bars), and in the tissue peripheral to the neuromast (light gray bars) for control neuromasts and during sequential $12 \mathrm{hr}$ intervals after laser-microbeam treatment of experimentals. $B$, Comparable incidence for large leukocytes that appear to be macrophages. The incidence of small leukocytes increased quickly to peak during the 12-24 hr interval after the laser treatment, but declined to control levels by the $48-60 \mathrm{hr}$ interval. In contrast, the incidence of large leukocytes increased rapidly, particularly among the mantle-type supporting cells, and remained elevated many times above control incidence for at least $108 \mathrm{hr}$ after the laser treatments.

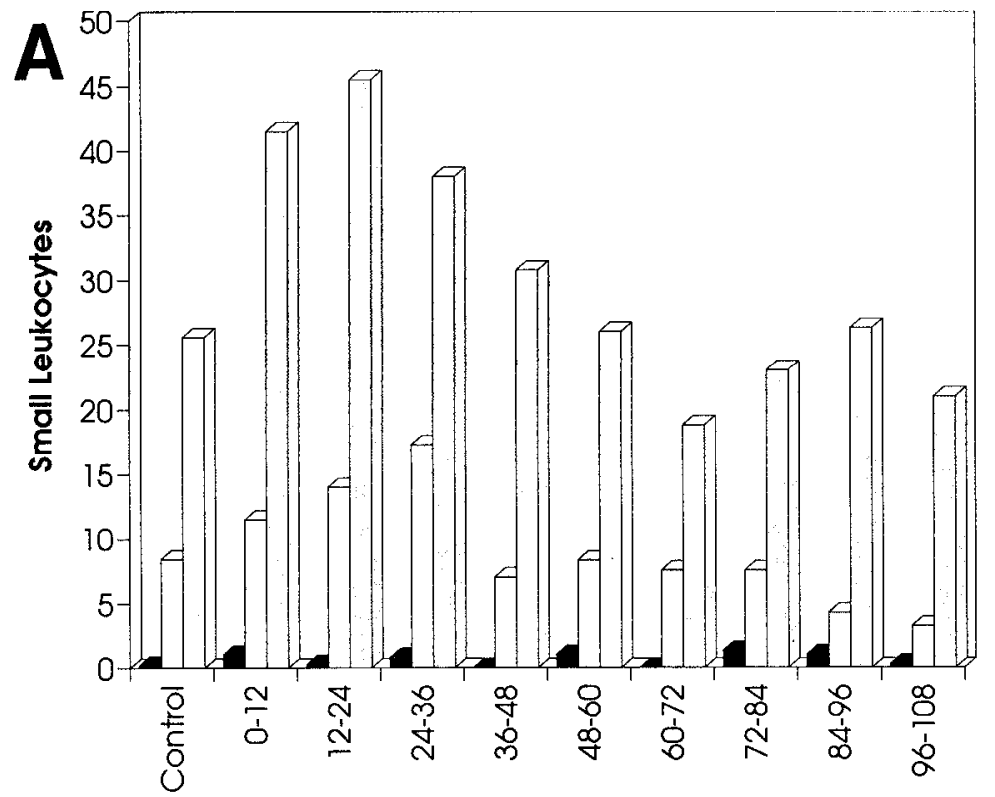

Time Interval

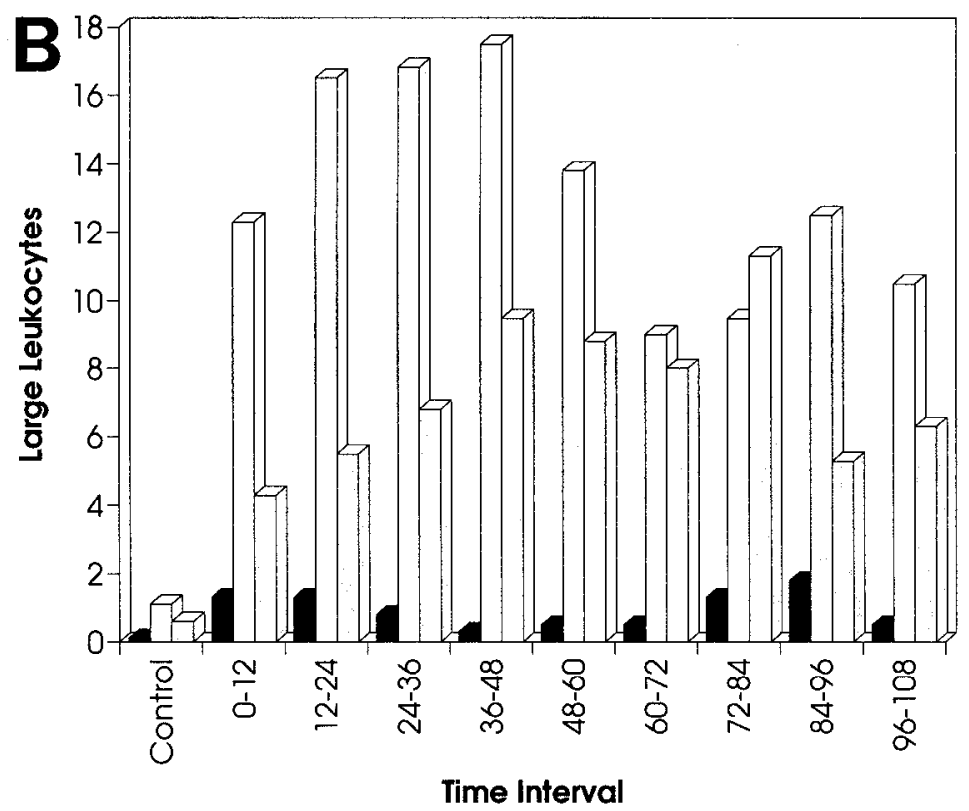

internal Mantle Peripheral supporting cells increased to a peak of $3.0 \pm 0.3$ mitoses $/ 12 \mathrm{hr}$ during the 48-60 hr observation interval and then declined slowly.

\section{Cell lineage}

In three experiments, the lineages that gave rise to replacement hair cells were determined via frame-by-frame analysis of timelapse video records that spanned the period between hair cell loss and the development of several regenerated hair cells 5-7 d later. The cell divisions and the phagocytic activities of macrophages that affected hair cell lineages in these three experiments are described below.

\section{Lineage experiment 1}

In the first lineage experiment, four replacement hair cells identified by nuclear morphology, the presence of hair bundles, and labeling with DASPEI were formed during the $112 \mathrm{hr}$ of time- lapse observation immediately after laser ablation of 11 preexisting hair cells (Fig. 5). Two of the 11 laser-treated hair cells were extruded from the epithelium, and 7 others were phagocytosed by large leukocytes during the initial $13 \mathrm{hr}$ of observation after the laser treatment. The two remaining hair cells were treated with the laser a second time, $24 \mathrm{hr}$ after the initial treatment. Those cells were phagocytosed by macrophages within $14 \mathrm{hr}$ of the second laser treatment. Eighteen mantle-type supporting cell mitoses and 12 internal supporting cell mitoses were observed during the $112 \mathrm{hr}$ of time-lapse observation. Twenty supporting cells were phagocytosed by large leukocytes during the period of observation. The lineages leading to the four replacement hair cells were traced through reverse playback of the time-lapse record to four cells present in the neuromast immediately after the initial laser treatment. Cells 1,2 , and 3 differenti- 


\begin{tabular}{|c|c|c|}
\hline \multirow[b]{2}{*}{ Cell type } & \multicolumn{2}{|l|}{ Treatment } \\
\hline & Control & Hair cell ablation \\
\hline Internal supporting cell & $0.3 \pm 0.2$ & $1.4 \pm 0.2^{*}$ \\
\hline \\
\hline cell & $0.2 \pm 0.2$ & $1.3 \pm 0.8^{*}$ \\
\hline Hair cell & 0 & $0.4 \pm 0.2^{*}$ \\
\hline
\end{tabular}

${ }^{*} p<0.01$, Student's $t$ distribution.

ated into hair cells directly from cells that were present in the epithelium at the start of the time-lapse recording. The cells that differentiated into those three hair cells did not divide during the time-lapse recording. The nuclei of cells 1,2 , and 3 developed the apically positioned spherical profiles that are characteristic of hair cell nuclei at 60,47 , and $30 \mathrm{hr}$ after the initial laser treatment. Cell 4 divided $36 \mathrm{hr}$ after the initial laser treatment. The progeny of that cell division differentiated asymmetrically, giving rise to one hair cell and one supporting cell. The cell that became a hair cell was first recognizable as such $83 \mathrm{hr}$ after the initial laser treatment, $47 \mathrm{hr}$ after the cell division that gave rise to it.

\section{Lineage experiment 2}

In a second lineage experiment, three replacement hair cells (identified by nuclear morphology and the presence of hair bundles) were formed during the $168 \mathrm{hr}$ of timc-lapsc rccording after laser ablation of 11 preexisting hair cells (Fig. 6). Five of the 11 laser-treated hair cells were extruded from the epithelium within 30 min of the treatment. Four of the remaining six hair cells were phagocytosed by large leukocytes during the $24 \mathrm{hr}$ period after the laser treatment. Two hair cells that survived the initial laser treatment were treated a second time, and those cells were removed by phagocytosis within 12 hr. A lotal of 23 mantle-type supporting cell mitoses and 20 internal supporting cell mitoses were observed during the time-lapse recording. Nineteen supporting cells were phagocytosed by macrophages during the recording.

It was possible to determine full lineages for two of the three hair cells that were regenerated. The lineage of the third hair cell could be traced back only as far as the mitosis that gave rise to it, because the immediate progenitor of that cell was rounded up in mitosis when the time-lapse recording was restarted after a feeding break. Consequently, the parent cell could not be identified with certainty in the time-lapse record that stopped before the break. By the end of the experiment, a secondary neuromast had begun to form because of proliferation of mantle-type supporting cells on the posterior side of the epithelium (Fig. 6, left).

\section{Cell 1}

Because of its position in the epithelium just after hair cell ablation, cell 1 was identified as an internal supporting cell. Cell 1 divided $50 \mathrm{hr}$ after the initial laser treatment, and the progeny of that cell division differentiated asymmetrically into a hair cell and an internal supporting cell that appeared to remain in contact. The daughter cell that became a hair cell developed the characteristic profile of a hair cell nucleus $74 \mathrm{hr}$ after the laser treatment, $24 \mathrm{hr}$ after the cell division that gave rise to it.

\section{Cell 2}

Because of its position in the neuromast at the start of the experiment, cell 2 could have been either an internal supporting
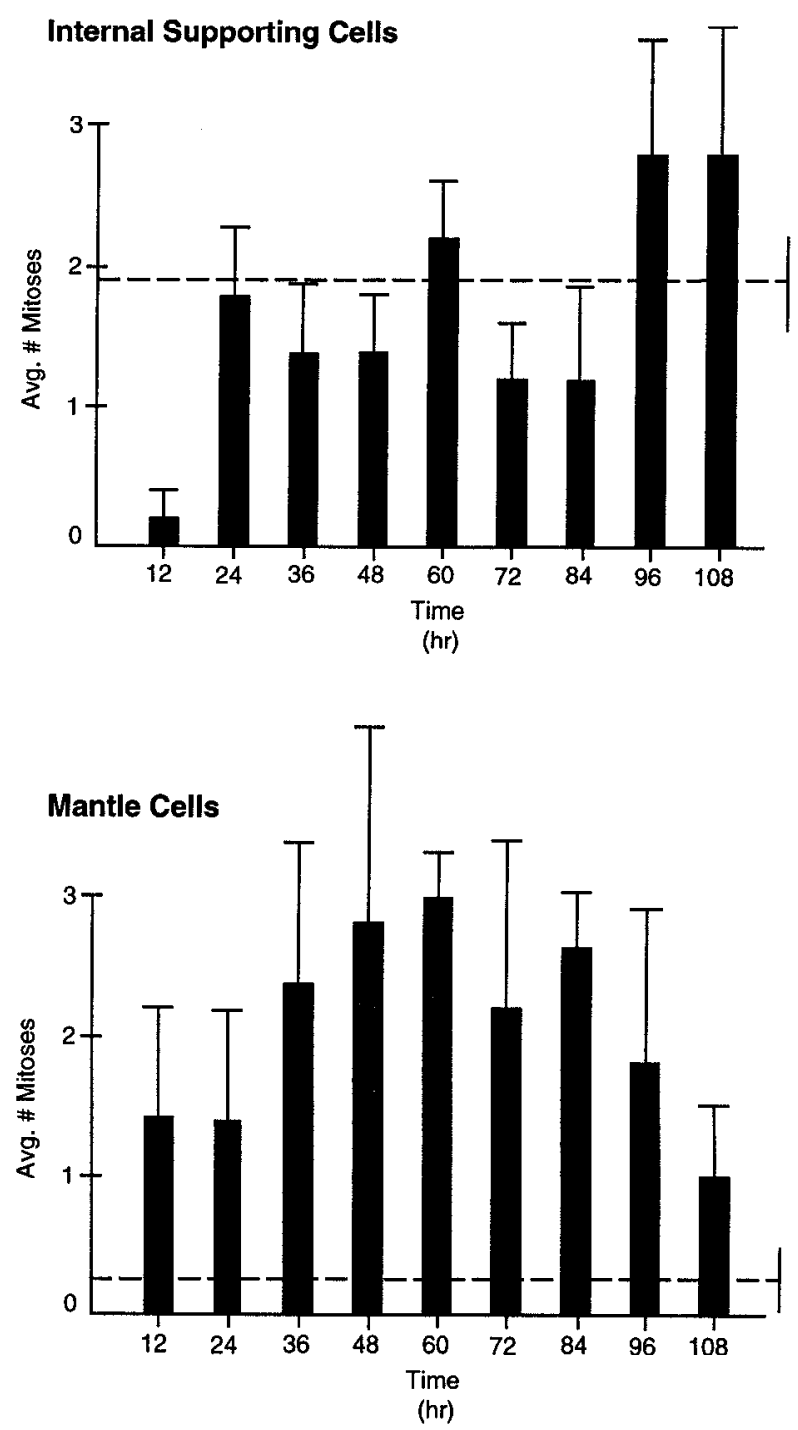

Figure 4. Average incidence of mitotic supporting cells in lateral line neuromasts after laser hair cell ablation. All preexisting hair cells in a single neuromast in five axolotls were killed by laser microsurgery at time 0 . The average number of mitoses observed in internal supporting cells (top) and mantle-type supporting cells (bottom) in the neuromasts during each of the 9 initial $12 \mathrm{hr}$ intervals of time-lapse observation are presented. Dashed lines represent the mitotic incidence in controls; vertical lines above each bar represent SE.

cell or a mantle-type supporting cell. During the initial $72 \mathrm{hr}$ of time-lapse observation, the phagocytic removal of cells in the center of the neuromast caused changes that brought cell 2 to a position nearer to the center than it had been at the start of the experiment. Cell 2 divided $76 \mathrm{hr}$ after the initial laser treatment, and the progeny of that cell division differentiated asymmetrically, giving rise to a hair cell and a supporting cell that did not remain in contact with each other. The daughter cell that became a hair cell was first identifiable as such $140 \mathrm{hr}$ after the laser treatment, $64 \mathrm{hr}$ after the cell division that gave rise to it.

\section{Cell 3}

The cell division that gave rise to the third replacement hair cell occurred $92 \mathrm{hr}$ after the laser treatment. One daughter cell from that mitosis differentiated into a hair cell and was first recognizable as such $140 \mathrm{hr}$ after the initial laser treatment, $48 \mathrm{hr}$ after the 
Figure 5. Cell lineages leading to regeneration of sensory hair cells after laser ablation of all preexisting hair cells in a lateral line neuromast. In this figure and in Figures 7 and 8, tracings of neuromasts that were taken from individual frames in the time-lapse video records are presented on the left. Hair cell ablation by laser-microbeam surgery was carried out at time 0 . Each tracing depicts the appearance of the neuromast at different times during regeneration, which can be approximated from the corresponding level in the timeline drawn vertically down the center of the figure. Numbers superimposed on the outlines of cells in the tracings label cells that were in lineages that gave rise to replacement hair cells. Mitoses are represented by bold circular profiles. The mitotic spindles are drawn in the orientations that were observed to occur. The progeny of mitoses that were part of hair cell lineages are indicated by the positioning of their identification numbers over the appropriate halves of the mitotic cells. On the right, lineage diagrams trace the descent of the numbered cells illustrated in the neuromast tracings. Branch points represent mitoses. Horizontal arrows indicate times when hair cells first became identifiable by morphological changes in their nuclei: $S c$, supporting cell; $H c$, hair cell; $M$, macrophage. Eleven hair cells were present in the neuromast at the start of the experiment depicted in this figure. They were killed individually using the laser microbeam at time 0 . During $112 \mathrm{hr}$ of subsequent time-lapse observation, four new hair cells developed $(1,2,3$, and 4$)$. Cells 1,2 , and 3 : three of the replacement hair were already present in the neuromast at the start of the time-lapse record, which began within minutes of the laser treatment. Those cells underwent a change in morphology without an observed cell division and became recognizable as differentiating hair cells at 60,47 , and $30 \mathrm{hr}$ after the laser treatment, respectively. The fourth replacement hair cell arose as one of the progeny of a cell division that occurred $36 \mathrm{hr}$ after the laser treatment. That cell division was "asymmetrical," i.e., one daughter cell became a hair cell and the other daughter cell appeared to become a supporting cell. The one daughter cell became recognizable as a differentiating hair cell $83 \mathrm{hr}$ after the initial laser treatment, $47 \mathrm{hr}$ after the cell division that gave rise to it (see text for details). cells differentiated directly from cells that
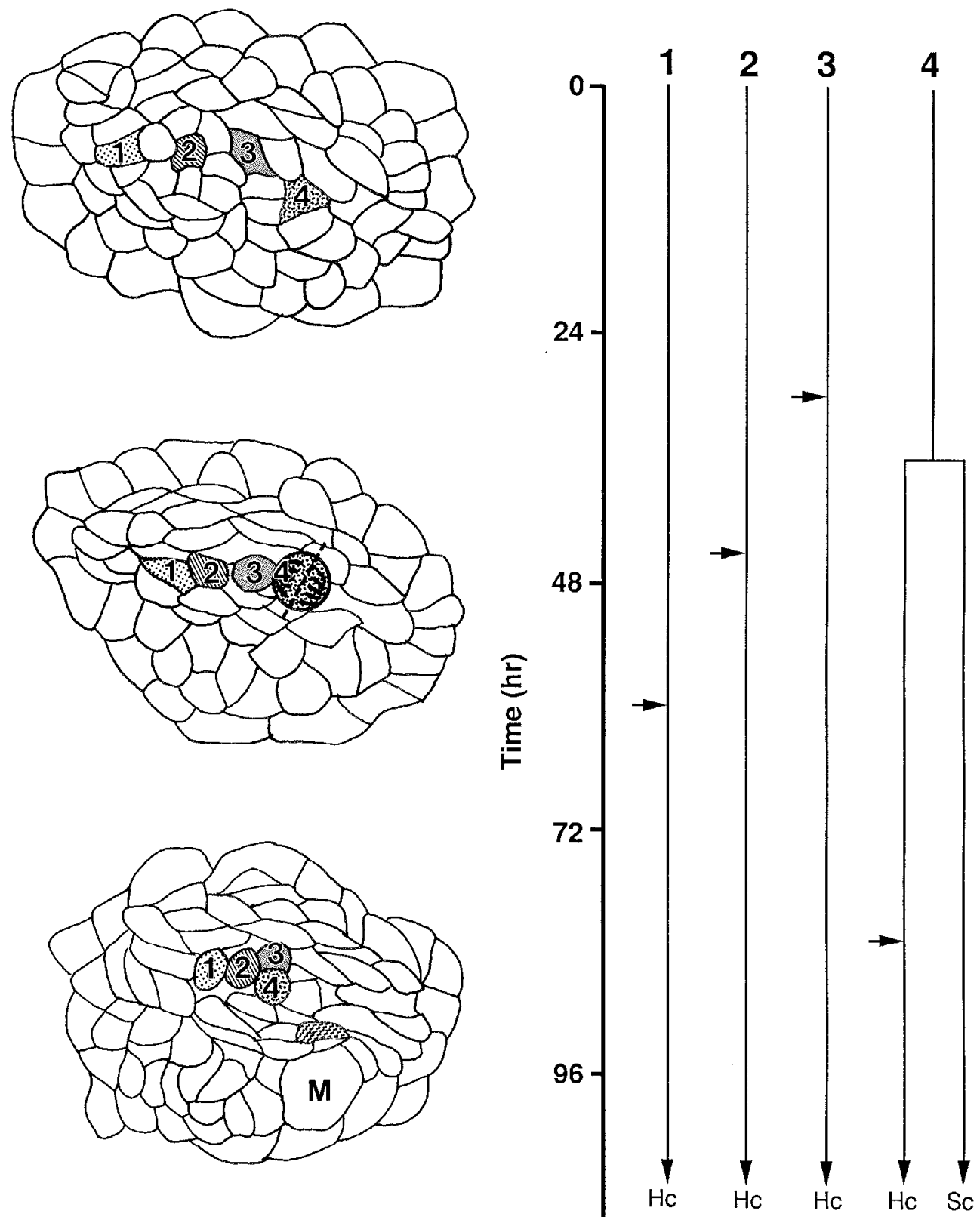

cell division that gave rise to it. The remaining daughter cell divided a second time, $14 \mathrm{hr}$ after the first mitosis and $106 \mathrm{hr}$ after the laser treatment. Both progeny of that cell division appeared to develop as internal supporting cells. Those three cells appeared to be in contact at the end of the experiment.

Our analysis focused on progeny that differentiated into hair cells during regeneration after laser treatments, but it is noteworthy that some progeny from the divisions of mantle-type supporting cells contributed to the formation of entirely new sensory organs in the form of secondary neuromasts. This occurred via "budding" of cells from the peripheral edge of the laser-treated organs, as illustrated in Figure 6. Budding is a normal process in the growth of aquatic amphibians, in which the primary neuromasts gradually give rise to "stitches" composed of small groups of neighboring neuromasts (Stone, 1937). The axolotls used in these experiments were at an earlier stage of development than the stage at which secondary neuromast formation would occur in controls, but after hair cells were killed by the microbeam the treated neuromasts sometimes were observed to give rise to secondary neuromasts by budding. It is likely, therefore, that 

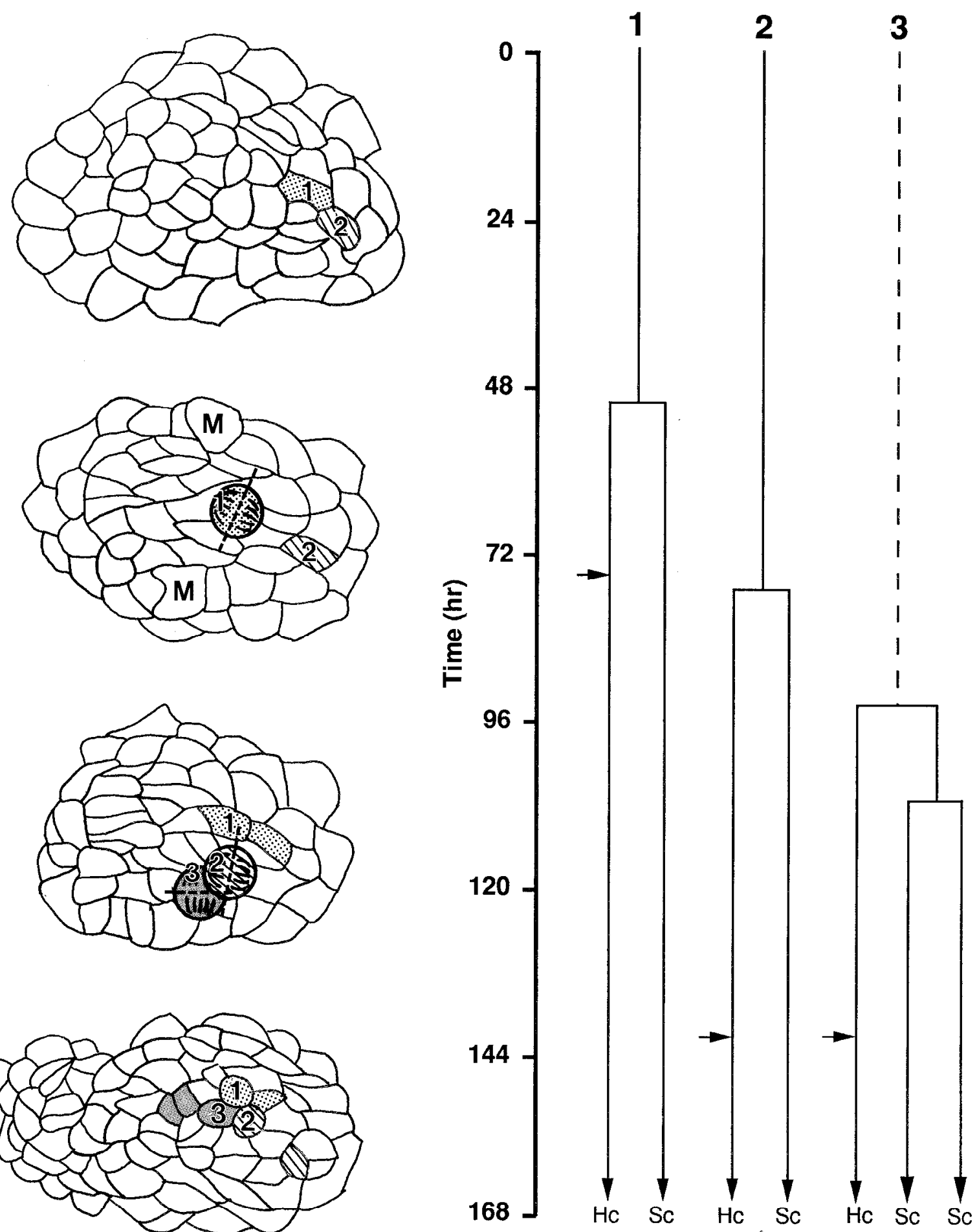

Figure 6. Cell lineages in the second complete time-lapse recording of regeneration leading to replacement hair cells after laser hair cell ablations. Eleven hair cells present in the neuromast were killed by the laser microbeam at time 0 . During the $168 \mathrm{hr}$ of time-lapse observation, three replacement hair cells were produced from cells within the treated epithelium. The complete lineages of two of the replacement hair cells (1 and 2) could be traced back to cells that were present in the epithelium immediately after the laser treatment. The lineage of the third replacement hair cell (3) could be traced back only to the cell division that gave rise to it, because the dividing cell was in prophase of mitosis at the time when the time-lapse recording was restarted after the record was stopped to give the axolotl a fecding brcak. Cclls 1 and 2 divided 50 and $76 \mathrm{hr}$, respcctively, after the initial laser treatment. Both of those cell divisions were asymmetrical, with one hair cell and one supporting cell produced from each. Hair cell 1 arose $74 \mathrm{hr}$ after the laser treatment (24 hr after the cell division that produced it). Hair cell 2 arose $140 \mathrm{hr}$ after the laser treatment ( $64 \mathrm{hr}$ after the cell division that produced it). The cell division that gave rise to hair cell 3 occurred $92 \mathrm{hr}$ after the initial laser treatment. One of the cells from that division differentiated as a hair cell, and the other produced from that division divided a second time, $14 \mathrm{hr}$ after the first mitosis and $98 \mathrm{hr}$ after the initial laser treatment. Both of the progeny of that cell division appeared to become supporting cells (see text for details; see Fig. 5 for notation). 
changed conditions within the laser-treated neuromast influence two processes: (1) the regeneration of cells within the damaged neuromast itself, and (2) the process of secondary neuromast formation that occurs via outward migration of proliferative multipotent cells from its edge.

\section{Lineage experiment 3}

In the third lineage experiment, two replacement hair cells (identified by nuclear morphology, the presence of hair bundles, and DASPEI labeling) were formed during $159 \mathrm{hr}$ of time-lapse observation immediately after the ablation of 14 hair cells. All of the laser-treated hair cells were extruded through the sensory pore of the neuromast within $30 \mathrm{~min}$. A total of 21 mantle-type supporting cell mitoses and 18 internal supporting cell mitoses were observed during the $159 \mathrm{hr}$ observation. Twenty-seven supporting cells were phagocytosed by macrophages. The cell lineages that led to the formation of the two replacement hair cells were traced back to two supporting cells present in the epithelium immediately after the laser treatment (Fig. 7).

\section{Cell 1}

At the start of the time-lapse recording, cell 1 was positioned in a location intermediate between the mantle-type and the internal supporting cells, so it could not be characterized reliably as a specific subtype. Cell 1 divided $47 \mathrm{hr}$ after the laser treatment, and both progeny divided a second time. One of the new cells divided $87 \mathrm{hr}$ after the laser treatment, and the other cell divided $97 \mathrm{hr}$ after the laser treatment. One of the cells produced from the mitosis at $87 \mathrm{hr}$ was phagocytosed by a large leukocyte at $128 \mathrm{hr}$, $41 \mathrm{hr}$ after the division that gave rise to it. The other developed the morphological appearance of an internal supporting cell by the end of the experiment. The cells produced from the division at $97 \mathrm{hr}$ differentiated asymmetrically. One became an internal supporting cell, and the other became a hair cell. The cell that differentiated into a hair cell was first recognizable as such 123 hr after the laser treatment, $26 \mathrm{hr}$ after the mitosis that gave rise to it.

\section{Cell 2}

At the start of the time-lapse recording, cell 2 appeared to be an internal supporting cell. Cell 2 divided $53 \mathrm{hr}$ after the laser treatment. One of the cells produced by that division was phagocytosed by a large leukocyte $114 \mathrm{hr}$ after the laser treatment, $61 \mathrm{hr}$ after the cell division that gave rise to it. When that cell was engulfed, it was located near the center of the epithelium, and it appeared to have begun to take on the appearance of a developing hair cell. The other cell produced by the division at $53 \mathrm{hr}$ divided a second time. The cells produced from that mitosis remained in contact and differentiated asymmetrically. One appeared to become a supporting cell, and the other became a hair cell. The cell that differentiated into a hair cell was first recognizable as such $123 \mathrm{hr}$ after the laser treatment, $29 \mathrm{hr}$ after the mitosis that gave rise to it.

\section{DISCUSSION}

Time-lapse video recording provided direct evidence of hair cells arising as progeny produced from the divisions of supporting cells. The results also showed that a hair cell and a supporting cell can arise from the same cell division. Observations from one neuromast could be interpreted as consistent with the idea that hair cells sometimes arise by conversion of preexisting cells within the epithelium without an intervening division, but more likely alternative interpretations could explain those observations, as discussed bclow. Small leukocytes and macrophages were attracted to the neuromasts within $1 \mathrm{hr}$ of the microbeam treatment. The incidence of small leukocytes returned to control levels 48-60 hr after the treatment. Macrophage incidence peaked just before the peak in the proliferation of the supporting cells. Macrophages phagocytosed many cells in the neuromast and remained in high numbers as the supporting cells continued to proliferate and as replacement hair cells differentiated. The observations are consistent with the possibility that macrophages influence this form of regenerative proliferation.

\section{Hair cell lineages}

Both internal supporting cells and mantle-type supporting cells can give rise to lineages that lead to hair cells. Cells that gave rise to replacement hair cells either differentiated directly as hair cells, without a cell division observed during the time-lapse period, or they underwent one or two divisions before differentiation of some of their progeny as hair cells (Figs. 5-7). Differentiated hair cells were never observed to undergo cell division.

The populations of internal supporting cells and mantle-type supporting cells differ in their responses to laser ablation of the hair cells. During the initial $12 \mathrm{hr}$ after laser treatment, the rate of proliferation in the internal supporting cells was significantly lower than the control rate, but the rate increased with time (see Fig. 4). In contrast, the incidence of proliferation in mantle-type supporting cells increased soon after the laser treatment. That proliferative activity peaked $48-60 \mathrm{hr}$ after the laser treatment, at many times the control rate. The peak of proliferation occurred just after a peak in the incidence of macrophages positioned among the mantle-type supporting cells (Figs. 3, 4).

An objective lens with a high numerical aperture and a shortwavelength laser light were used to restrict the focused size of the

\footnotetext{
Figure 7. Cell lineages in the third complete time-lapse experiment leading to regeneration of sensory hair cells after laser ablations. Fourteen hair cells present in the neuromast were killed by laser treatment. During the $159 \mathrm{hr}$ of time-lapse recording, two replacement hair cells were produced from cells within the treated epithelium ( 1 and 2). Cell 1: Cell 1 divided $47 \mathrm{hr}$ after the initial laser treatment, and both of the daughter cells produced by that cell division divided a second time. One daughter cell divided $87 \mathrm{hr}$ after the laser treatment, and the other daughter cell divided $97 \mathrm{hr}$ after the laser treatment. One of the daughter cells of the mitosis at $87 \mathrm{hr}$ was phagocytosed by a large leukocyte at $128 \mathrm{hr}, 41 \mathrm{hr}$ after the division that gave rise to it ( $x$, phagocytosis). The other daughter cell had the morphological appearance of an internal supporting cell at the end of the experiment. The daughter cells of the division at $97 \mathrm{hr}$ differentiated asymmetrically. One daughter cell became a supporting cell ( $\mathrm{Sc}$ ), and the other daughter cell became a hair cell $(H c)$. The cell that differentiated into a hair cell was first recognizable as such $123 \mathrm{hr}$ after the laser treatment, $26 \mathrm{hr}$ after the mitosis that gave rise to it. Cell 2: Cell 2 divided $53 \mathrm{hr}$ after the laser treatment. One of the daughter cells of that cell division was phagocytosed by a large leukocyte 114 hr after the laser treatment, $61 \mathrm{hr}$ after the cell division that gave rise to it. At the time that the cell was engulfed, it was located near the center of the epithelium, and it had begun to take on the appearance of a differentiating hair cell. The second daughter cell produced by the cell division that occurred at $53 \mathrm{hr}$ divided a second time, $94 \mathrm{hr}$ after the laser treatment. The daughter cells of that mitosis differentiated asymmetrically. One daughter cell had the appearance of a supporting cell at the end of the experiment, and the other daughter cell differentiated into a hair cell. It first became recognizable as a differentiating hair cell $123 \mathrm{hr}$ after the laser treatment, $29 \mathrm{hr}$ after the mitosis that gave rise to it (see text for details).
} 

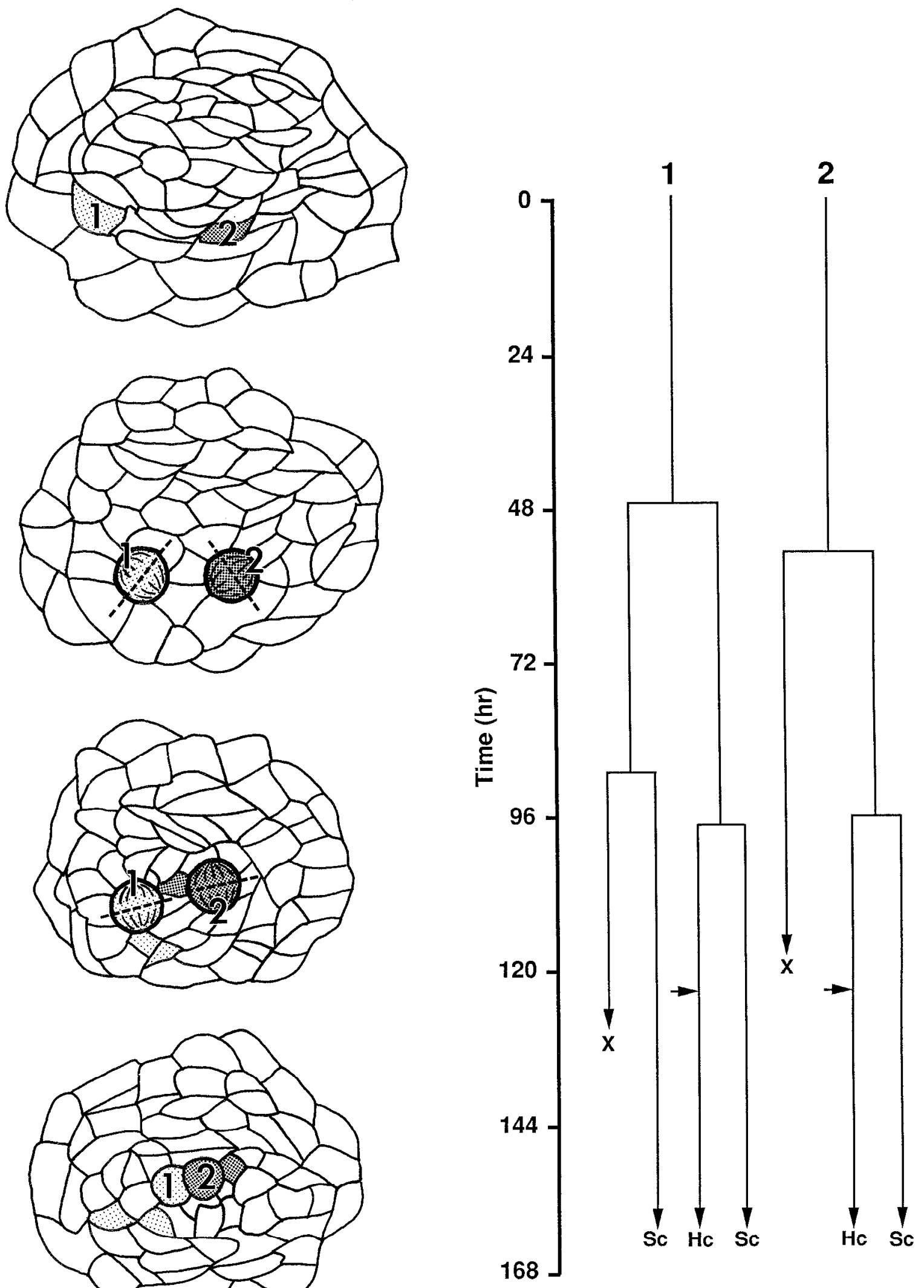
3 nsec pulses of the microbeam. Histological examinations have demonstrated that the supporting cells immediately adjacent to hair cell lesions made with this apparatus appear normal (Balak et al., 1990; Kelley et al., 1995). It should be noted, however, that the initial decline in the incidence of cell divisions in the internal supporting cells (see Fig. 4) still might be related to inadvertent damage resulting from laser irradiation caused by the proximity of those cells to the targeted hair cells.

The first regenerated hair cells consistently appeared in the center of each laser-treated neuromast, suggesting that the position of an undifferentiated cell influences the decision to differentiate as a hair cell. It has been suggested that lateral inhibitory interactions guide fate decisions in regenerating and developing hair cell epithelia (Corwin et al., 1991; Lewis, 1991) via cell-cell signaling mechanisms analogous with those that determine cell fate in the development of the sensory bristles and compound eye of Drosophila (Ghysen and Dambly-Chaudière, 1988, 1989; Tomlinson, 1988; Basler and Hafen, 1989; Zipursky and Rubin, 1994).

The central cells that differentiated as the first replacement hair cells were located consistently at mid-depths in the sensory epithelium, suggesting that position relative to the underlying extracellular matrix also contributes to the decision to differentiate as a hair cell. Adhesion to extracellular matrices influences cell fate in the cornea, testis, endothelium, and retina (Hay, 1980; Hadley ct al., 1985; Rch ct al., 1987; Grant ct al., 1989; Rch, 1989). In the hair cell epithelia, supporting cells appear to remain in contact with the basement membrane, whereas differentiated hair cells do not have basement membrane contacts. We hypothesize that one stage in the determination of hair cell fate depends on events that remove an undifferentiated cell from contact with the basement membrane or prevent a new cell from establishing that contact. Observations of the initial stages of hair cell regeneration in this study and in previous reports have provided evidence consistent with that hypothesis (Balak et al., 1990; Kornblum et al., 1990; Jones and Corwin, 1993).

\section{The role of supporting cells}

With few exceptions, specific markers for supporting cells are lacking (Goodyear et al., 1995), so a supporting cell can be identified with only limited confidence. In contrast, hair cells usually can be identified with confidence even at an early stage. The absence of specific markers also limits the ability to distinguish mature supporting cells from dormant progenitor cells or other potential subtypes that could be present in the epithelia (Presson and Popper, 1990; Presson et al., 1994) or from undifferentiated progeny produced from recent divisions.

In cultured embryonic mammalian organs of Corti, time-lapse microscopy and $\left[{ }^{3} \mathrm{H}\right]$ thymidine autoradiography have shown that outer hair cells can be replaced via a nonproliferative mechanism involving a change in fate for preexisting cells beneath the site of a laser-microbeam lesion (Kelley et al., 1991, 1995). It has been proposed that nonproliferative replacement of lost hair cells also occurs during postembryonic life in birds and frogs (Raphael and Miller, 1991; Baird et al., 1993). The lineage results illustrated in Figure 5 could be interpreted as being consistent with such a phenomenon. One mechanistic hypothesis is that new cells become functional supporting cells when they have developed to a state of intermediate or partial differentiation, but under conditions that result from trauma they could differentiate further to give rise to replacement hair cells via a nonproliferative conversion of cell phenotype. Such a conversion would be somewhat analogous with the progression through states of intermediate differentiation that is followed by maturing lymphocytes (Sprent et al., 1991; Sprent, 1993; Alberts et al., 1994). The direct observations of cell lineage in this study indicate that sister progeny from the same cell division can become either supporting cells or hair cells, suggesting that both progeny of such a division start with equivalent potentials for cell phenotype differentiation.

It should be noted, however, that alternative explanations could account for the current evidence. Supporting cells divide and new hair cells differentiate continuously as lateral line sensory epithelia of axolotls grow during postembryonic life. Therefore, at the time of the laser treatment, the cells in Figure 5 that eventually differentiated as hair cells actually could have been undifferentiated progeny that had been produced by cell divisions occurring a short time before the start of the recording. Such cells could have been progressing toward differentiation into hair cells already, or they could have been at a stage at which their fate had not been determined. In evaluating the alternative interpretations, it is important to note that the three hair cells that differentiated directly from preexisting cells became recognizable as hair cells at 30,47 , and $60 \mathrm{hr}$ after the laser treatment. Those times are within the normal range of intervals between a cell division and the recognizable differentiation of progeny as hair cells (range 24-64 hr). Furthermore, those cells were the first to become recognizable as hair cells in this study, and there were no indications of nonproliferative hair ccll replaccments obscrved in any of the other time-lapse recordings. Considerable evidence has established that mature and, in some species, mitotically quiescent supporting cells in fish, amphibians, birds, and mammals retain the ability to re-enter the cell cycle to divide during postembryonic life (Corwin, 1981, 1985; Corwin and Cotanche, 1988; Girod et al., 1989; Raphael, 1993; Warchol et al., 1993). Labeling with $\left[{ }^{3} H\right]$ thymidine has established that the new cells arising from those supporting cell divisions at sites of lesions can differentiate as replacement hair cells and supporting cells. The observations presented in Figure 5 are potentially consistent with such a proliferative mechanism for hair cell regeneration.

\section{Patterns of hair cell differentiation}

The dividing cells that gave rise to regenerated hair cells were multipotent. One of the progeny differentiated as a hair cell, and the other either continued to proliferate or appeared to become a supporting cell (Figs. 5-7). Investigations in Xenopus laevis also concluded that lateral line organs were formed via asymmetrical divisions in the proliferative placode (Winklbauer and Hausen, 1983a,b, 1985a,b). These observations contrast with indirect evidence which suggests that hair cells frequently are formed in pairs in the larger lateral line canal organs of bullseye and cardinal fishes (Rouse and Pickles, 1991). Isolated pairs of hair cells of the same apparent cellular age, determined on the basis of the small size of their hair bundles, were observed to be scattered throughout the more homogeneous mature hair bundles in the epithelia. It appears that hair cells can differentiate singly in some instances and in pairs in others. Such patterns are consistent with the hypothesis that fate decisions are under the control of mechanisms that respond to stochastic changes in cell environments. The apparent paired production of hair cells in canal neuromasts of some teleost fishes also may be an adaptation that contributes to cell turnover or to the large size of those epithelia, which contain several thousand hair cells each (Rouse and Pickles, 1991), rather than the 30 or fewer that are present in the neuromasts of axolotls and Xenopus. 


\section{Leukocytes}

Leukocytes phagocytosed laser-treated hair cells that were not extruded from neuromasts as well as many untreated supporting cells (Table 1). Supporting cells that were phagocytosed after nearby laser treatments could have suffered damage that we did not recognize. But a majority of the phagocytosis of supporting cells occurred $2 \mathrm{~d}$ or more after the laser treatment. This is after the time during which a laser-evoked response would have been expected. Newly produced cells were phagocytosed on several occasions (Fig. 7), and supporting cells were phagocytosed in the control neuromasts (Table 1). We conclude that phagocytic removal is a normal process in these cell populations and is not dependent only on laser-mediated damage. Leukocytes in $X$. laevis blood smears share morphological characteristics and staining patterns similar to those of leukocytes in mammals (Hadji-Azimi et al., 1987). An earlier time-lapse investigation of the lateral line used morphological, behavioral, and histochemical criteria similar to those in mammals to distinguish motile cells observed in axolotls as small granulocylic leukocytes and larger macrophages (Jones and Corwin, 1993).

Leukocytes are involved in both forms of lateral line regeneration that we have investigated. After amputation of the tip of the tail, leukocytes undergo a spatial redistribution that brings them to the neuromasts that will give rise to proliferating cells that form a regenerative placode (Jones and Corwin, 1993). After hair cell loss evoked by laser-microbeam treatments within otherwise intact neuromasts, macrophage numbers increased rapidly in the vicinity of the treated neuromasts. These macrophages could influence the nearby cells of the neuromasts via enzymatic activity or growth factor secretions. Macrophages have the potential to secrete transforming growth factor- $\alpha$, basic fibroblast growth factor, and epidermal growth factor, as well as other mitogenic growth factors and cytokines (Nathan, 1987; Unanue and Allen, 1987; Riches, 1988) that have mitogenic effects in many tissues (Nathan, 1987; Rappolee et al., 1988; Higashiyanna et al., 1991). In that respect, it is noteworthy that the peak of the incidence of macrophages in the vicinity of the treated neuromasts occurred just before the peak in proliferation of the mantle-type supporting cells. Additional experimentation is required to determine whether this timing reflects a causal relationship between macrophage activity and the increased proliferation of these hair cell progenitors.

\section{REFERENCES}

Alberts B, Bray D, Lewis J, Raff M, Roberts K, Watson JD (1994) The molecular biology of the cell, 3rd ed. New York: Garland.

Baird RA, Torres MA, Schuff NR (1993) Hair cell regeneration in the bullfrog vestibular otolith organs following aminoglycoside toxicity. Hear Res 65:164-174.

Balak KJ, Corwin JT, Jones JE (1990) Regenerated lair cells can originate from supporting cell progeny: evidence from phototoxicity and laser ablation experiments in the lateral line system. J Neurosci 10:2502-2512.

Basler K, Hafen E (1989) Ubiquitous expression of sevenless: positiondependent specification of cell fate. Science 243:931-934.

Berns MW, Aist J, Edwards J, Strahs K, Girton J, McNeill P, Rattner JB, Kitzes M, Hammer-Wilson M, Liaw H-H, Siemens A, Koonce M, Peterson S, Brenner S, Burt J, Walter R, Bryant J, van Dyk D, Coulombe J, Cahill T, Berns GS (1981) Laser microsurgery in cell and developmental biology. Science 213:505-513.

Bredberg G (1968) Cellular pattern and nerve supply of the human organ of Corti. Acta Otolaryngol [Stockh] 236:1-136.

Callazo A, Fraser SE, Mabee PA (1994) A dual origin for vertebrate mechanoreceptors. Science 264:426-430.

Corwin JT (1981) Postembryonic production and aging of inner ear hair cells in sharks. J Comp Neurol 201:541-553.
Corwin JT (1983) Postembryonic growth of the macula neglecta auditory detector in the ray, Raja clavata: continual increases in hair cell number, neural convergence, and physiological sensitivity. J Comp Neurol 217:345-356.

Corwin JT (1985) Perpetual production of hair cells and maturational changes in hair cell ultrastructure accompany postembryonic growth in an amphibian ear. Proc Natl Acad Sci USA 82:3911-3915.

Corwin JT (1986) Regeneration and self-repair in hair cell epithelia: experimental evaluation of capacitics and limitations. In: Biology of change in otolaryngology (Ruben RJ, Van deWater TR, Rubel EW, eds), pp 291-304. New York: Elsevier.

Corwin JT, Cotanche DA (1988) Regeneration of sensory hair cells after acoustic trauma. Science 240:1772-1774.

Corwin JT, Balak KJ, Borden PC (1989) Cellular events underlying the regenerative replacement of lateral line sensory epithelia in amphibians. In: The mechanosensory lateral line: neurobiology and evolution (Coombs S, Görner P, Münz PH, eds), pp 161-183. New York: Springer.

Corwin JT, Jones JE, Katayama AK, Kelley MW, Warchol ME (1991) Hair cell regeneration: the identities of progenitor cells, potential triggers, and instructive cues. In: Regeneration of vertebrate sensory receptor cells (Ciba Foundation Symposium 160), pp 103-130. Chichester: Wiley.

Cotanche DA (1987) Regeneration of hair cell stereociliary bundles in the chick cochlea following severe acoustic trauma. Hear Res 30:181-196.

Flock $\AA$, Jørgensen JM (1974) The ultrastructure of lateral line sense organs in the juvenile salamander, Ambystoma mexicanum. Cell Tissue Res 152:283-292.

Ghysen A, Dambly-Chaudière C (1988) From DNA to form: the achaetescute complex. Genes Dev 2:495-501.

Ghysen A, Dambly-Chaudière C (1989) Genesis of the Drosophila peripheral nervous system. Trends Genet 5:251-255.

Girod DA, Duckcrt LG, Rubcl EW (1989) Possible precursors of regenerated hair cells in the avian cochlea following acoustic trauma. Hear Res 42:175-194.

Goodyear R, Holley M, Richardson G (1995) Hair and supporting-cell differentiation during the development of the avian inner ear. J Comp Neurol 351:81-93.

Grant DS, Tashiro KI, Segui-Real B, Yamada Y, Martin GR, Kleinman HK (1989) Two different laminin domains mediate the differentiation of human endothelial cells into capillary-like structures in vitro. Cell 58:933-943.

Hadji-Azimi I, Coosemans V, Canicatti C (1987) Atlas of adult Xenopus laevis hematology. Dev Comp Immunol 11:807-874.

Hadley MA, Byers SW, Suárez-Quian CA, Kleinman HK, Dym M (1985) Extracellular matrix regulates Sertoli cell differentiation, testicular formation, and germ cell development in vitro. J Cell Biol 101:1511-1522.

Harrison RG (1904) Experimentelle untersuchung über die entwicklung der sinnesorgane de siten linie bei den amphibien. Arch Mikrosk Anat 63:35-149.

Hay ED (1980) Development of the vertebrate cornea. Int Rev Cytol 63:263-322.

Higashiyama S, Abraham JA, Miller J, Fiddes J, Klagsbrun M (1991) A heparin-binding growth factor secreted by macrophages that is related to EGF. Science 251:936-939.

Jones JE, Corwin JT (1993) Replacement of lateral line sensory organs during tail regeneration in axolotls: identification of progenitor cells and analysis of lcukocytc activity. J Ncurosci 13:1022-1034.

J $\emptyset$ rgensen JM (1981) On a possible hair cell turn-over in the inner ear of the caecilian Ichthyophis glutinosus (Amphibia:Gymnophiona). Acta Zool [Stockh] 62:171-186.

Jørgensen JM (1989) Evolution of octavolateralis sensory cells. In: The mechanosensory lateral line: neurobiology and evolution (Coombs S, Görner P, Münz PH, eds), pp 115-145. New York: Springer.

Jørgensen JM, Mathiesen C (1988) The avian inner ear: continuous production of hair cells in vestibular organs, but not in the auditory papilla. Naturwissenschaften 75:319-320.

Katayama A, Corwin JT (1989) Cell production in the chicken cochlea. J Comp Neurol 281:129-135.

Katayama A, Corwin JT (1993) Cochlear cytogenesis visualized through pulse labeling of chick embryos in culture. J Comp Neurol 333:28-40.

Kelley MW, Laverack CM, Corwin JT (1991) Recovery of the mannmalian organ of Corti after laser microbeam ablation of embryonic hair cells. Soc Neurosci Abstr 17:631. 
Kelley MW, Talrcja DR, Corwin JT (1995) Replacement of hair cells after laser microbeam irradiation in cultured organs of Corti from embryonic and neonatal mice. J Neurosci 15:3013-3026.

Kornblum HI, Corwin JT, Trevarrow B (1990) Selective labeling of sensory hair cells and neurons in auditory, vestibular, and lateral line systems by a monoclonal antibody. J Comp Neurol 301:162-170.

Lewis J (1991) Rules for the production of sensory cells. In: Regeneration of vertebrate sensory receptor cells (Bock G, Whelan J, eds), pp 25-39. New York: Wiley.

Nathan CF (1987) Secretory products of macrophages. J Clin Invest 79:319-326.

Northcutt RG, Catania KC, Criley BB (1994) Development of lateral line organs in the axolotl. J Comp Neurol 340:480-514.

Oesterle E, Cunningham DE, Rubel EW (1992) Ultrastructure of hyaline, border, and vacuole cells in chick inner ear. J Comp Neurol 318:64-82

Popper AN, Hoxter B (1984) Growth of a fish ear. I. Quantitative analysis of hair cell and ganglion cell proliferation. Hear Res 15:133-142.

Presson JC, Popper AN (1990) Possible precursors to new hair cells, support cells, and Schwann cells in the ear of a post-embryonic fish. Hear Res 46:9-22.

Presson JC, Smith T, Mentz L (1994) Death and damage to S-phase cells by the drug c-ARA up-regulates cell proliferation in the ear of a postembryonic fish. Assoc Res Otolaryngol Abstr 17:114.

Raphael Y (1992) Evidence for supporting cell mitosis in response to acoustic trauma in the avian inner ear. $J$ Neurocytol 21:663-671.

Raphael Y (1993) Reorganization of the chick basilar papilla after acoustic trauma. J Comp Neurol 330:521-532.

Raphael Y, Miller JM (1991) Dual mechanisms for production of new hair cells in regenerating avian cochlea. Soc Neurosci Abstr 17:1214.

Rappolee SA, Mark D, Banda MJ, Werb Z (1988) Wound macrophages express TGF- $\alpha$ and other growth factors in vivo: analysis by mRNA phenotyping. Science 241:708-712.

Reh TA (1989) The regulation of neuronal production during retinal neurogenesis. In: Development of the vertebrate retina (Finaly BL, Sengelaub DR, eds), pp 43-68. New York: Plenum.

Reh TA, Nagy T, Gretton H (1987) Retinal pigmented epithelial cells induced to transdifferentiate to neurons by laminin. Nature 330:68-71.

Riches DWH (1988) The multiple roles of macrophages in wound healing. In: The molecular and cellular biology of wound repair (Clark RAF, Henson PM, eds), pp 213-239. Plenum: New York.

Roberson DF, Weisleder P, Bohrer PS, Rubel EW (1992) Ongoing pro duction of sensory cells in the vestibular epithelium of the chick. Hear Res 57:166-174

Rouse GW, Pickles JO (1991) Paired development of hair cells in neuromasts of the teleost lateral line. Proc R Soc Lond [Biol] 246:123-128.

Rubel EW, Oesterle EC, Weisleder P (1991) Hair cell regeneration in the avian inner ear. In: Regeneration of vertebrate sensory receptor cells (Ciba Foundation Symposium 160), pp 77-102. Chichester: Wiley.
Ruben RJ (1967) Development of the inmer ear of the mouse: a radioautographic study of terminal mitoses. Acta Otolaryngol [Stockh] 220:1-44.

Ryals BM, Rubel EW (1988) Hair cell regeneration after acoustic trauma in adult Coturnix quail. Science 240:1774-1776.

Speidel CC (1947) Correlated studies of sense organs and nerves of the lateral-line in living frog tadpoles. J Comp Neurol 87:29-55.

Speidel CC (1948) Correlated studies of sense organs and nerves of the lateral-line in living frog tadpoles. II. The trophic influence of specific nerve supply as revealed by prolonged observations of denervated and reinnervated organs. Am J Anat 82:277-320.

Sprent J (1993) Life spans of naive, memory and effector lymphocytes. Curr Opin Immunol 5:433-438.

Sprent J, Schaefer M, Hurd M, Surh CD, Yacov R (1991) Mature murine $B$ and $T$ cells transferred to SCID mice can survive indefinitely and many maintain a virgin phenotype. J Exp Med 174:717-728.

Stone LS (1933) The development of lateral line sense organs in amphibians observed in living and vital-stained preparations. J Comp Neurol $57: 507-540$

Stone LS (1937) Further experimental studies of the development of lateral-line sense organ's in the amphibians observed in living preparations. J Comp Neurol 68:83-115.

Tester AL, Kendall JI (1969) Morphology of the lateralis canal system in the shark genus Carcharinus. Pac Sci 23:1-16.

Tomlinson A (1988) Cellular interactions in the developing Drosophila eye. Development 104:183-193.

Unanue ER, Allen PM (1987) The basis for the immunoregulatory role of macrophages and other accessory cells. Science 236:551-557.

Warchol MW, Lambert PR, Goldstein BJ, Forge A, Corwin JT (1993) Regenerative proliferation in inner ear sensory epithelia from adult guinea pigs and humans. Science 259:1619-1622.

Weisleder P, Rubel EW (1993) Hair cell regeneration after streptomycin toxicity in the avian vestibular epithelium. J Comp Neurol 331:97-110.

Winklbauer R, Hausen P (1983a) Development of the lateral line system in Xenopus laevis. I. Normal development and cell movement in the supraorbital system. J Embryol Exp Morphol 76:265-281.

Winklbauer R, Hausen P (1983b) Development of the lateral line system in Xenopus laevis. II. Cell multiplication and organ formation in the supraorbital system. J Embryol Exp Morphol 76:283-296.

Winklbauer R, Hausen P (1985a) Development of the lateral line system in Xenopus laevis. III. Development of the supraorbital system in triploid embryos and larvae. J Embryol Exp Morphol 88:183-192.

Winklbauer R, Hausen P (1985b) Development of the lateral line systen in Xenopus laevis. IV. Pattern formation in the supraorbital system. J Embryol Exp Morphol 88:193-207.

Wright MR (1947) Regeneration and degeneration experiments on lateral line nerves and sense organs in anurans. J Exp Zool 105:221-257.

Zipursky SL, Rubin GM (1994) Determination of neuronal cell fate: lessons from the R7 neuron of Drosophila. Annu Rev Neurosci 17: 373-397. 